\title{
Methodological considerations for blood flow restricted resistance exercise
}

\author{
Christopher A. Fahs, Jeremy P. Loenneke, Lindy M. Rossow, Robert S. Thiebaud, Michael G. Bemben
}

Blood flow restricted (BFR) resistance exercise has become a popular area of research. However, studies use a range of blood flow restriction and resistance exercise protocols.

Objectives: To provide an overview of the methods used for BFR resistance exercise for individuals interested in utilizing BFR training and for researchers studying the acute and chronic effects of BFR resistance exercise.

Design: A systematic review.

Method: BFR resistance training studies with muscular strength and hypertrophy as main outcomes were identified. Resistance exercise protocol and blood flow restriction protocol were compared between these studies. Acute BFR resistance exercise studies comparing different BFR protocols were also examined.

Results: Continuous, partial arterial blood flow restriction during resistance exercise appears to be tolerable and effective for increasing both limb and trunk muscle strength and hypertrophy. Compared to non-BFR exercise, blood flow restriction produces an additive effect when combined with resistance exercise loads of $<50 \%$ one-repetition maximum. Optimal BFR resistance training frequency may be higher (2x daily) than high-load resistance exercise.

Conclusions: Restrictive cuff size, pressure, and limb circumference affect the degree of blood flow restriction and should be carefully considered when performing or prescribing BFR resistance exercise. The volume and frequency of BFR resistance exercise may depend on the trainee's capabilities and goals.

(Journal of Trainology 2012; 1:14-22)

Key words: Muscle hypertrophy $\square$ strength $\boldsymbol{\square}$ kaatsu $\boldsymbol{\square}$ training.

$\mathrm{B}$ lood flow restricted (BFR) exercise training, coined "KAATSU Training", was first made available for public use in Japan. ${ }^{1}$ Since then, numerous studies have examined the effects of BFR resistance exercise on skeletal muscle hypertrophy and strength gains, as well as on neural, endocrine, and cardiovascular responses. The novelty of BFR resistance exercise is that relatively low exercise intensities (e.g. $20 \%$ of one-repetition maximum, 1-RM) can be utilized to elicit skeletal muscle hypertrophy and increase muscular strength. Even low-intensity aerobic exercise (e.g. walking, cycling), when combined with blood flow restriction, may be effective for increasing strength and hypertrophy. ${ }^{2}$ Thus, BFR exercise has a wide range of practical applications, from performance enhancement in athletes to combating muscle atrophy in clinical populations.

To restrict blood flow during resistance exercise, a restrictive cuff or band (typically a pneumatic cuff) is placed on the most proximal portion of the exercising limb which reduces arterial blood inflow to the working muscle and occludes venous return resulting in the pooling of venous blood around the exercising muscle. Although there are likely many mechanisms involved in the adaptations to BFR exercise, optimizing muscle fiber recruitment appears to be critical. Thus, low-load BFR resistance exercise serves as an effective way to reach the same endpoint as reached with other forms of resistance exercise. However, BFR resistance training introduces more variables than standard training. Individual differences (e.g. limb size) as well as methodological differences (e.g. restrictive cuff size and pressure and resistance exercise protocol) are variables that must be considered with BFR resistance exercise. Manipulation of these variables will affect the degree to which blood flow is restricted during exercise. This may affect the acute responses and ultimately training adaptations to this type of exercise. Therefore, the purpose of this article is to summarize the different methodologies used in BFR resistance training studies to provide a resource for individuals who may be interested in utilizing this training technique and for researchers who are interested in studying the acute and chronic effects of BFR resistance exercise.

\section{Blood flow restriction protocol}

Currently, there is no standard method for the application of blood flow restriction during resistance exercise. Differences exist in the restrictive cuff type (cuff size and material),

Received March 29, 2012; accepted April 26, 2012

From the Neuromuscular Laboratory, Department of Health and Exercise Science, University of Oklahoma

Communicated by Takashi Abe, $\mathrm{PhD}$

Corresponding to Mr. Christopher A. Fahs, 1401 Asp Ave, Norman, OK 73019. Neuromuscular Laboratory, Department of Health and Exercise

Science, University of Oklahoma. E-mail: chris.fahs@ou.edu

Journal of Trainology 2012:1:14-22 @2012 The Active Aging Research Center http://trainology.org/ 
restrictive cuff pressure, and duration of restrictive pressure application which may affect the degree of blood flow restriction during exercise. Manipulation of the degree of blood flow restriction during resistance exercise has been shown to affect muscle activation and the degree of muscle fatigue. Thus, the variables that affect the degree of blood flow restriction warrant careful attention.

Blood flow restriction device. A variety of devices, typically pneumatic cuffs, of different sizes have been used for BFR resistance exercise. The size of the cuff, especially the width, is an important variable to consider as wider restrictive cuffs have been shown to be more effective in restricting arterial blood flow at lower inflation pressures compared to narrower restrictive cuffs. ${ }^{3}$ Therefore, in order to occlude venous return without causing complete arterial occlusion both cuff size and cuff pressure are important. Many studies have used KAATSU Master (Sato Sports Plaza, Tokyo, Japan) elastic restrictive cuffs, which are typically $3 \mathrm{~cm}$ wide for upper body or $5 \mathrm{~cm}$ wide for lower body exercise. KAATSU Sportswear (PHENIX Co. Ltd., Tokyo, Japan), which has elastic belts attached to the ends of specially designed sleeves and pants, has also been used to restrict blood flow during exercise. ${ }^{4}$ Other studies have used a variety of restrictive cuffs ranging in width from $2 \mathrm{~cm}$ for upper body exercise up to $20.5 \mathrm{~cm}$ for the lower body. Unfortunately, many studies do not report the width of the cuff used for blood flow restriction. If utilizing wider restrictive cuffs for BFR exercise in combination with supra-systolic cuff pressures, the exercise bout may become uncomfortable and the exercise volume may be limited. High levels of pain in the quadriceps have been reported during acute BFR knee extensor exercise using a cuff $13.5 \mathrm{~cm}$ wide inflated to 200 mmHg during exercise. ${ }^{5}$ Although many BFR resistance training studies do not measure pain as a main outcome, at least one study explicitly noted no incidence of pain during BFR bench press training when using narrower $(3.3 \mathrm{~cm}$ wide $)$ restrictive cuffs. ${ }^{6}$ Comparing the perceptual response to BFR knee extension exercise with different size restrictive cuffs, wider $(13.5 \mathrm{~cm})$ restrictive cuffs cause greater ratings of pain and perceived exertion during exercise and limit the exercise volume compared to narrow $(5 \mathrm{~cm})$ restrictive cuffs inflated to the same pressure. ${ }^{7}$ Cuff pressure should be adjusted depending on the restrictive cuff width to account for the differences in the degree of blood flow restriction between narrow and wide cuffs and to minimize participant discomfort.

For low-load (20-30\% 1-RM) lower body BFR resistance exercise, restrictive cuffs either $4 \mathrm{~cm}^{8}, 5 \mathrm{~cm}^{9}$ or $9 \mathrm{~cm}^{10}$ in width inflated to pressures of $160-240 \mathrm{mmHg}$ have all been shown effective for increasing knee extensor muscle strength and hypertrophy. In contrast, a $13 \mathrm{~cm}$ wide restrictive cuff inflated to $230 \mathrm{mmHg}$ causing complete arterial occlusion hindered the hypertrophic response to BFR knee extensor exercise specifically at the site at which the cuff was applied. ${ }^{11}$ Distal to the restrictive cuff, mid-thigh quadriceps CSA increased $(0.21 \%$ increase per session) following the training although no significant increase in strength was observed. ${ }^{11}$ It should be noted that intermittent rather than continuous blood flow restriction was utilized in this study. This study highlights the fact that wider restrictive cuffs inflated to pressures used with narrower cuffs can cause complete arterial occlusion during exercise and may limit the effectiveness of BFR resistance training.

For upper body BFR resistance exercise, many studies have shown relatively narrow $(3-3.3 \mathrm{~cm}$ wide) restrictive cuffs inflated to pressures of $100-160 \mathrm{mmHg}$ on the upper arms to be effective for improving strength and hypertrophy. ${ }^{6,12-14}$ BFR elbow flexor training using a $7 \mathrm{~cm}$ wide restrictive cuff has also been shown to enhance isometric strength compared to non-BFR elbow flexor training. ${ }^{15}$ In contrast, another study reported no difference in the increase in isotonic or isokinetic elbow flexor strength following BFR training using a $12 \mathrm{~cm}$ wide cuff or non-BFR training. ${ }^{16}$

Alternative devices, including elastic knee wraps, have also been used for BFR exercise. Elastic knee wraps ( $7.6 \mathrm{~cm}$ wide) applied during BFR knee extensor exercise did not augment metabolic stress (lactate) but did increase ratings of perceived exertion compared to exercise without the knee wraps. ${ }^{17}$ However, the elastic knee wraps were removed during the rest periods which may partially explain the lack of metabolic stress to the BFR exercise protocol. The authors concluded that the use of elastic knee wraps to restrict blood flow intermittently during exercise would not be recommended. ${ }^{17}$ However, BFR resistance training utilizing $5 \mathrm{~cm}$ wide elastic bands with Velcro for the upper and lower limbs were effective in increasing strength and hypertrophy following BFR resistance training. ${ }^{18}$

Restriction pressure. Most studies have utilized a restrictive cuff pressure of between 140-240 $\mathrm{mmHg}$ for lower body exercise and between $100-160 \mathrm{mmHg}$ for upper body exercise in the upright position. The efficacy of BFR resistance exercise appears to come from the restriction of venous outflow which occurs at low pressures (7-35 mmHg depending on body position). There may also be variable degree of arterial flow restriction depending on the amount of soft tissue surrounding the artery. ${ }^{19}$ It should also be noted that if using an elastic-type cuff to restrict blood flow it is important to consider how tightly the cuffs are applied initially as the initial pressure of the cuffs (i.e. pressure applied to the limbs before inflation) may affect the level of tissue oxygenation at any given applied pressure (i.e. pressure when the cuffs are inflated)..$^{20}$

Although this section will focus on the muscular effects of different restrictive cuff pressures during BFR exercise, it should be noted that reductions in arterial blood flow to skeletal muscle increase the chemoreflex causing greater elevations in heart rate (HR) and blood pressure (BP) during exercise. For example, during walk exercise, blood flow restriction has been shown to increase the $\mathrm{HR}$ and $\mathrm{BP}$ response. ${ }^{21}$ Furthermore, higher $(200 \mathrm{mmHg})$ restrictive cuff pressures increase $\mathrm{HR}$ and $\mathrm{BP}$ to a greater extent during exercise compared to lower $(160 \mathrm{mmHg})$ cuff pressures. ${ }^{22}$ Complete arterial occlusion (300 $\mathrm{mmHg}$ cuff pressure) during unilateral elbow flexion resistance exercise has also been shown to increase HR to a greater extent than moderate arterial occlusion (160 mmHg cuff pressure) ${ }^{23}$ 
During supine rest, superficial femoral artery blood flow is partially restricted with restrictive cuff pressures up to 250 mmHg (5 cm width). ${ }^{24}$ During seated BFR knee extensor exercise, superficial femoral artery blood flow is reduced by almost $50 \%$ using a pressure of $160-180 \mathrm{mmHg}(5 \mathrm{~cm}$ width). ${ }^{25}$ Therefore, to cause partial but not complete arterial flow restriction to the muscle, many studies have utilized lower body restrictive cuff pressures in the range of 160-240 mmHg. ${ }^{8-10,26-33}$ Other studies have used a restrictive cuff pressure based on the participant's resting systolic blood pressure (SBP), typically $130 \%$ SBP or roughly $130-180$ mmHg. ${ }^{34,35}$ However, restrictive cuff pressures in this range may not be appropriate for all individuals. In the supine position, complete arterial occlusion in the leg can occur using either narrow (5 cm width) and wide $(13.5 \mathrm{~cm}$ width) cuffs inflated to relatively low pressures (120 and $100 \mathrm{mmHg}$, respectively). ${ }^{36}$ The pressure at which arterial occlusion in the leg occurs appears to be influenced most by limb circumference and not necessarily by brachial systolic blood pressure. ${ }^{36}$ Therefore, a restrictive cuff pressure based on limb size may be more advisable. Other studies have noted that the fatigue response and degree of hypoxia in the muscle during BFR exercise may be influenced by limb circumference. ${ }^{37}$ Phosphocreatine depletion has been shown to be greater during unilateral plantar flexion BFR resistance exercise in endurance athletes compared to sprint athletes which, although not reported, may be related to limb size differences resulting in different amounts of blood flow restriction between groups. ${ }^{38}$ With studies noting the potential influence of limb size, some groups have used an individualized restriction cuff pressure of $80 \%$ of the pressure which causes complete arterial occlusion. ${ }^{39,40}$

For lower body BFR resistance exercise, high restrictive cuff pressures $(300 \mathrm{mmHg})$ causing complete arterial occlusion may cause participant discomfort ${ }^{41}$ and prevent completion of a full exercise bout. ${ }^{23}$ When using a wide (18.5 $\mathrm{cm}$ ) restrictive cuff during BFR plantar flexion exercise, restrictive cuff pressures of $\sim 150 \mathrm{mmHg}$ and $200 \mathrm{mmHg}$ increased intramuscular inorganic phosphate to a similar extent. ${ }^{42}$ However, when using a narrow cuff $(5 \mathrm{~cm})$, a slightly higher restrictive cuff pressure $(230 \mathrm{mmHg})$ caused a greater increase in intramuscular inorganic phosphate during exercise than a moderate $(180 \mathrm{mmHg})$ restrictive cuff pressure. ${ }^{43}$ This suggests that in order to increase fatigue and motor unit recruitment with low loads during lower body BFR exercise, slightly higher restrictive cuff pressure may be optimal with narrow cuffs while lower restrictive cuff pressures may be sufficient with wider cuffs.

Comparing the effect of lower body BFR resistance training using different cuff pressures, similar increases in isokinetic knee extensor strength following BFR resistance training using restriction cuff ( $7.7 \mathrm{~cm}$ width) pressures of 50, 150, or 250 mmHg have been observed. ${ }^{44}$ However, only BFR training using restriction pressures of 50 and $150 \mathrm{mmHg}$ produced significant increases in muscle endurance while BFR training with a cuff pressure of $250 \mathrm{mmHg}$ resulted in higher ratings of perceived exertion as well as complains of numbness in the legs. ${ }^{44}$ This study also noted almost complete occlusion of arterial blood flow with $250 \mathrm{mmHg}$ cuff pressure. This study supports the recommendation that restrictive cuff pressure should not cause complete arterial occlusion.

Compared to lower body BFR exercise, lower restrictive cuff pressures (100-160 mmHg) are generally utilized for upper body BFR resistance exercise due to difference in limb size. A study examining the impact of different restrictive cuff pressures during upper body BFR resistance exercise observed that a restrictive cuff $(3.3 \mathrm{~cm}$ width) pressure of $100 \mathrm{mmHg}$ was more effective in increasing motor unit recruitment than a restrictive cuff pressure of $50 \mathrm{mmHg} .{ }^{12}$ Subsequent studies have suggested that slightly higher restrictive cuff $(3.3 \mathrm{~cm}$ width) pressure of $150-160 \mathrm{mmHg}$ may be preferable to 100 $\mathrm{mmHg}$ for increasing the metabolic stress and muscle fiber recruitment during upper body BFR exercise. ${ }^{37,45}$ However, very high restrictive cuff pressures $(300 \mathrm{mmHg}$ ) causing complete arterial occlusion can prevent completion of a full exercise bout which would likely decrease the efficacy of repeated training bouts. ${ }^{23}$

Many BFR resistance training studies $6,89,13,14,26,27,30-33,46$ have progressively increased restrictive cuff pressure by $10-20$ $\mathrm{mmHg}$ on a weekly or biweekly basis during training as a way to increase overload and increase training adaptations. Typically, restrictive cuff pressures for lower body exercises start on the first week of training at $140-160 \mathrm{mmHg}$ and increase up to $180-240 \mathrm{mmHg}$ on the final week of training. Restrictive cuff pressures have also been increased based on the trainees' ratings of perceived exertion (RPE), increasing the restrictive cuff pressure if RPE was below a certain threshold (e.g. $<16$ on Borg 6-20 scale) during the previous training session. ${ }^{27}$ No study has examined the impact of progressively increasing cuff pressure during BFR exercise training so it is not clear if increases in restrictive cuff pressure cause greater training adaptations to occur.

Continuous versus intermittent blood flow restriction. BFR resistance training studies have used either continuous or intermittent blood flow restriction during the exercise training. During intermittent BFR exercise, muscle fatigue can quickly be reduced during rest periods between exercise sets, similar to free flow exercise. During resistance exercise some blood flow restriction occurs due to the muscle contraction. Therefore, external blood flow restriction applied only during the exercise period may not provide an added stimulus (i.e. induce muscle fatigue) to cause muscular adaptations. In fact, during lowload resistance exercise, continuous blood flow restriction has been shown to be more effective in causing muscle fatigue ${ }^{41}$ and metabolic stress ${ }^{47}$ compared to intermittent blood flow restriction.

With BFR resistance training, intermittent blood flow restriction may or may not enhance strength adaptations compared to non-BFR resistance training. For example, knee extension exercise with intermittent blood flow restriction only produced a $3.4 \%$ increase in mid-thigh knee extensor CSA and no significant increases in strength. ${ }^{11}$ In contrast, another study observed an $18 \%$ increase in force during a maximal voluntary contraction of the triceps surae after 4-weeks of training with 
intermittent blood flow restriction. ${ }^{48}$ The latter study did not observe any increase in strength in the contralateral limb trained without any blood flow restriction suggesting that even intermittent blood flow restriction may augment strength adaptations.

Summary. Evidence suggests that moderate restrictive cuff pressures (160-240 mmHg for lower body; 100-160 mmHg for upper body) are effective in facilitating type II fiber recruitment and increasing metabolic stress during low-load exercise for most individuals. However, restrictive cuff width and the individual's limb size may affect the degree of blood flow restriction. The restrictive cuff pressures may need to be lowered if utilizing a wider restrictive cuff $(>10 \mathrm{~cm})$ or if the individual has small limb circumferences. Complete arterial occlusion during BFR exercise is not advisable and thus, determining the pressure at which arterial occlusion in the limb occurs on each individual may be ideal to base restrictive cuff pressures. Data also suggest continuous blood flow restriction is more effective than intermittent blood flow restriction for increasing fast twitch fiber recruitment and metabolic stress during low-load exercise.

\section{Resistance exercise protocol}

Compared to traditional high-load resistance exercise, BFR resistance exercise uses a lower exercise load coupled with a higher exercise volume to cause significant metabolic stress within the muscle leading to the recruitment of larger motor units.

Exercise load. BFR resistance training studies have used resistance exercise intensities ranging from $15 \% \mathrm{MVC}^{11}$ to $6-$ RM ( 80\% 1-RM) ${ }^{39}$ with many studies using an exercise load of $20 \% 1-\mathrm{RM}^{9,10,26-28,30-33,40,46,49}$ and some using 30\% 1 $\mathrm{RM}^{6,8,13,14,34,50}$ to increase muscle size and strength. These exercise loads are based primarily on acute BFR studies indicating low-loads can cause substantial metabolic stress and fatigue. Some evidence suggests that the metabolic stress during BFR exercise is dependent on the exercise load. During unilateral plantar flexion exercise, a BFR resistance exercise load of $30 \%$ 1-RM caused a similar intramuscular metabolic stress as high-load (65\% 1-RM) resistance exercise while a load of 40\% 1-RM caused an even greater degree of metabolic stress. ${ }^{42}$ Another study compared BFR knee extension exercise intensities of $20 \%$ and $40 \%$ maximal voluntary contraction (MVC) and suggested an exercise load of $20 \%$ MVC is preferable based on observations that lower loads were more comfortable and tolerable than higher loads. ${ }^{41}$

BFR resistance training with low loads (20-30\% 1-RM) has repeatedly been shown to improve muscle strength and hypertrophy to a greater extent than low-load training without blood flow restriction ${ }^{9} 10,12,40,48,51,52$ and to a similar extent as high-load ( $80 \%$ 1-RM) resistance training. ${ }^{12,27,34}$ The hypertrophic effects of low (20\% 1-RM) and moderate-load (50\% 1-RM) BFR may be similar as studies ${ }^{10,29}$ have demonstrated similar increases in muscle hypertrophy $(16 \%$ and $15 \%$ increase in muscle cross sectional area) when using loads of either $20 \%$ or $50 \%$ 1-RM with BFR knee extensor exercise. However, for increasing strength slightly higher BFR exercise loads may provide greater adaptation. For example, one study compared unilateral BFR plantar flexion exercise training using a load of either $25 \%$ 1-RM or $50 \% 1$ $\mathrm{RM}$ and documented greater increases in strength using a load of 50\% 1-RM. ${ }^{51}$ Another study also observed a greater increase in knee extensor strength following BFR training using 50\% 1-RM (14.3\% average increase in isokinetic torque $)^{29}$ compared to BFR training using a load of $20 \%$ 1-RM (9.2\% average increase in isokinetic torque). ${ }^{10}$ However, using if using training loads of 50\% 1-RM or greater blood flow restriction may not always be beneficial. Other groups observed no additional benefit of BFR (compared to non-BFR exercise at the same load) in terms of muscle strength or hypertrophy following either elbow flexor training at 50\% 1$\mathrm{RM}^{16}$ or knee extensor training at $60 \%$ or $80 \% 1-\mathrm{RM}^{39}$. One of the limitations of using higher loads during BFR exercise is that venous outflow may be enhanced, limiting the effectiveness of the blood flow restriction. ${ }^{12}$

Collectively, current evidence would suggest a load of $>50 \%$ 1-RM for BFR resistance exercise may not be practical or any more effective than lower (20-30\% 1-RM) intensities for inducing muscle hypertrophy. For increasing strength, higher BFR exercise intensities may elicit greater increases, although the adaptation may be driven more by the exercise load rather than the blood flow restriction per se.

Exercise volume. With evidence indicating that the metabolic accumulation and hypoxia experienced during BFR exercise enhances motor unit recruitment and the endocrine response to exercise, overall exercise volume may also play a significant role in the muscular adaptations. One of the benefits of BFR resistance exercise is that it reduces the total volume of exercise needed to elicit strength and hypertrophy gains. Studies have shown greater increases in strength and hypertrophy following BFR training compared to non-BFR exercise training of an equivalent volume..$^{10,29}$

Many BFR resistance training studies have utilized a protocol of one set of 30 repetitions followed by three sets of 15 repetitions for each exercise while other studies have had participants complete all sets to volitional fatigue. Theoretically, BFR exercise to volitional fatigue would produce a greater metabolic accumulation and potentially lead to greater adaptations than exercise terminated prior to volitional fatigue. Studies in which participants performed BFR exercise training to volitional fatigue as well as short of fatigue have found increases in muscular strength and hypertrophy. Quadriceps cross sectional area (CSA) increased $\sim 16 \%$ following 8 weeks (16 training bouts) of training when participants performed five sets of BFR knee extensor exercise to volitional fatigue. ${ }^{10}$ Twelve bouts of four sets (75 repetitions) of BFR knee extensor exercise over just six days produced a $3.5 \%$ increase in quadriceps $\mathrm{CSA} .{ }^{9}$ Comparing strength adaptations, one study observed an $8 \%$ increase in isometric knee extensor strength following four weeks of BFR exercise to volitional fatigue ${ }^{34}$ which is slightly higher than that observed in another study ${ }^{9}$ which found a $5.7 \%$ increase in isometric knee extensor strength following the same number 
(12) of training sessions over six days. However, based on the differences in training duration in the aforementioned studies, it is difficult to determine an optimal exercise volume for BFR resistance training. Future studies should examine the impact of BFR exercise volume on the muscular adaptations.

Training frequency. Higher training frequency can facilitate more rapid training adaptations. Tolerable resistance training frequency may be higher with low-load BFR compared to high-load resistance exercise. BFR exercise training frequency has ranged from as low as twice per week ${ }^{8,10,12,16,29,39,40,46,53,54}$ up to a frequency of twice daily $9,13,26,28,32,33$. Condensing training duration may be of particular interest for individuals recovering from injury as discussed previously. ${ }^{55}$ BFR resistance exercise performed twice daily has been shown to be effective for increasing muscle size and strength with increases in strength and hypertrophy observed after just six days. ${ }^{9,33}$ However, delayed onset muscle soreness following exercise may limit training frequency if exercise is performed to volitional fatigue. For example, muscle soreness 24 to 48 hours following acute knee extensor exercise to volitional fatigue has been shown to be greater following BFR exercise compared to non-BFR exercise. ${ }^{56,57}$ Similar to high-load resistance exercise training, there must a balance between frequency and volume of exercise training. BFR resistance exercise terminated prior to volitional fatigue may more suitable for individuals needing to achieve the greatest amount of adaptations in the shortest duration possible. It should be noted that the BFR resistance training studies utilizing higher training frequencies (i.e. twice daily) did not have participants complete the exercise to volitional fatigue.

Exercise choice. The majority of BFR resistance exercise studies have utilized either knee extension exercise or elbow flexion exercise. However, a variety of other exercises including compound exercises such as the squat ${ }^{4,26,33,50,53}$ and bench press ${ }^{6,13,14}$ have been performed with blood flow restriction. Additionally, blood flow restriction has been utilized with a circuit training program without an external $\operatorname{load}^{4}$ and as part of rehabilitation exercises ${ }^{58}$ and a physical therapy program ${ }^{59}$. BFR squat and bench press exercises have even been implemented as an adjunct to regular off-season strength training in division I college football players. ${ }^{18}$ One of the criticisms of BFR exercise is that the restrictive cuffs may only be applied to the limbs and thus, it may not be feasible to increase strength or hypertrophy in the chest or back muscles. However, blood flow restriction to the arms during bench press exercise training produced greater pectoralis muscle hypertrophy compared to training without blood flow restriction. ${ }^{13}$ When combined with non-BFR upper body resistance exercise, lower body (knee flexion and extension) BFR exercise has also been shown to enhance strength and hypertrophy increases in the elbow flexor muscles. ${ }^{8}$

Summary. Blood flow restriction appears to be efficacious when combined with resistance exercise with loads up to $50 \%$ 1-RM. Evidence does not suggest BFR resistance exercise needs to be performed to volitional fatigue. In fact, delayed onset muscle soreness may be greater if BFR resistance exercise is performed to volitional fatigue and this may potentially limit training frequency. If BFR exercise is terminated prior to volitional fatigue, training frequency may be greater than high-load resistance exercise and allow for rapid progression. BFR resistance exercise is effective for causing muscle hypertrophy in both trunk and appendicular muscles and can be effectively used with either single-joint or compound lifts.

\section{Conclusions}

The majority of research performed on BFR resistance exercise thus far appears to support the efficacy and safety of this type of low-load training as an alternative to high-load resistance training. However, as research is growing, more variations in the methods exist which may affect both the safety and efficacy of this type of exercise. From the available literature, we suggest the following:

1) When using relatively narrow restrictive cuffs $(5-6 \mathrm{~cm}$ for lower body or 3-4 cm for upper body), restrictive cuff pressures between $160-240 \mathrm{mmHg}$ for the lower body and 100-160 may be appropriate for most individuals. However, cuff pressure should be adjusted based on cuff width and an individual's limb circumference to ensure only partial arterial occlusion.

2) Continuous rather than intermittent blood flow restriction during exercise is preferable to increase the metabolic demands and motor unit recruitment during low-load resistance exercise.

3) A BFR resistance exercise load of $<50 \%$ 1-RM is sufficient to produce increases in muscle strength and hypertrophy.

4) BFR resistance exercise frequency as low as twice per week up to twice daily may be effective for increasing muscle strength and hypertrophy.

5) Limb blood flow restriction can be used in combination with either single joint or multi joint exercise to cause either limb or trunk muscle adaptations.

\section{Practical implications}

BFR resistance exercise has become increasing popular in the literature and appears to be an effective alternative to highload resistance exercise for improving muscle strength and hypertrophy. Manipulating the blood flow restriction protocol as well as the resistance exercise protocol is important to consider for the individual prescribing or performing BFR resistance exercise.

\section{Acknowledgements}

There has been no financial assistance with this project.

\section{References}

1. Sato Y. The history and future of KAATSU Training. Int $J$ KAATSU Training Res. 2005; 1(1):1-5.

2. Abe T, Kearns CF, Sato Y. Muscle size and strength are increased following walk training with restricted venous blood flow from the leg 
muscle, Kaatsu-walk training. J Appl Physiol. 2006; 100(5):1460-1466.

3. Crenshaw AG, Hargens AR, Gershuni DH, et al. Wide tourniquet cuffs more effective at lower inflation pressures. Acta Orthop Scand. 1988; 59(4):447-451.

4. Ishii $\mathrm{N}$, Madarame $\mathrm{H}$, Odagiri $\mathrm{K}$, et al. Circuit training without external load induces hypertrophy in lower-limb muscles when combined with moderate venous occlusion. Int J KAATSU Training Res. 2005; 1(24-28.

5. Wernbom M, Augustsson J, Thomee R. Effects of vascular occlusion on muscular endurance in dynamic knee extension exercise at different submaximal loads. J Strength Cond Res. 2006; 20(2):372-377.

6. Yasuda T, Ogasawara R, Sakamaki M, et al. Combined effects of lowintensity blood flow restriction training and high-intensity resistance training on muscle strength and size. Eur J Appl Physiol. 2011; 111(10): 2525-2533.

7. Rossow LM, Fahs CA, Loenneke JP, et al. Cardiovascular and perceptual responses to blood-flow-restricted resistance exercise with differing restrictive cuffs. Clin Physiol Funct Imaging. 2012.

8. Madarame H, Neya M, Ochi E, et al. Cross-transfer effects of resistance training with blood flow restriction. Med Sci Sports Exerc. 2008; 40(2):258-263

9. Fujita T, Brechue WF, Kurita K, et al. Increased muscle volume and strength following six days of low-intensity resistance training with restricted muscle blood flow. Int J KAATSU Training Res. 2008; 4(1):1-8.

10. Takarada Y, Tsuruta T, Ishii N. Cooperative effects of exercise and occlusive stimuli on muscular function in low-intensity resistance exercise with moderate vascular occlusion. Jpn J Physiol. 2004; 54(6):585-592.

11. Kacin A, Strazar K. Frequent low-load ischemic resistance exercise to failure enhances muscle oxygen delivery and endurance capacity. Scand $J$ Med Sci Sports. 2011; 21(6):231-241.

12. Takarada Y, Takazawa H, Sato Y, et al. Effects of resistance exercise combined with moderate vascular occlusion on muscular function in humans. J Appl Physiol. 2000; 88(6):2097-2106.

13. Yasuda T, Fujita S, Ogasawara R, et al. Effects of low-intensity bench press training with restricted arm muscle blood flow on chest muscle hypertrophy: a pilot study. Clin Physiol Funct Imaging. 2010; 30(5):338343.

14. Yasuda T, Ogasawara R, Sakamaki M, et al. Relationship between limb and trunk muscle hypertrophy following high-intensity resistance training and blood flow-restricted low-intensity resistance training. Clin Physiol Funct Imaging. 2011; 31(5):347-351.

15. Moore DR, Burgomaster KA, Schofield LM, et al. Neuromuscular adaptations in human muscle following low intensity resistance training with vascular occlusion. Eur J Appl Physiol. 2004; 92(4-5):399-406.

16. Burgomaster KA, Moore DR, Schofield LM, et al. Resistance training with vascular occlusion: metabolic adaptations in human muscle. Med Sci Sports Exerc. 2003; 35(7):1203-1208.

17. Loenneke JP, Kearney ML, Thrower AD, et al. The acute response of practical occlusion in the knee extensors. J Strength Cond Res. 2010; 24(10):2831-2834

18. Yamanaka T, Farley RS, Caputo JL. Occlusion Training Increases Muscular Strength in Division Ia Football Players. J Strength Cond Res. 2012;

19. Shaw JA, Murray DG. The relationship between tourniquet pressure and underlying soft-tissue pressure in the thigh. J Bone Joint Surg Am. 1982; 64(8):1148-1152.

20. Karabulut M, McCarron J, Abe T, et al. The effects of different initial restrictive pressures used to reduce blood flow and thigh composition on tissue oxygenation of the quadriceps. J Sports Sci. 2011; 29(9):951-958.

21. Renzi CP, Tanaka H, Sugawara J. Effects of Leg Blood Flow Restriction during Walking on Cardiovascular Function. Med Sci Sports Exerc. 2010; 42(4):726-732.

22. Sakamaki M, Fujita S, Sato Y, et al. Blood pressure response to slow walking combined with KAATSU in the elderly. Int $J$ KAATSU Training Res. 2008; 4(1):17-20.

23. Yasuda T, Brechue WF, Fujita T, et al. Muscle activation during low- intensity muscle contractions with restricted blood flow. J Sports Sci. 2009; 27(5):479-489.

24. Iida H, Kurano M, Takano H, et al. Hemodynamic and neurohumoral responses to the restriction of femoral blood flow by KAATSU in healthy subjects. Eur J Appl Physiol. 2007; 100(3):275-285.

25. Takano $\mathrm{H}$, Morita $\mathrm{T}$, Iida $\mathrm{H}$, et al. Hemodynamic and hormonal responses to a short-term low-intensity resistance exercise with the reduction of muscle blood flow. Eur J Appl Physiol. 2005; 95(1):65-73.

26. Abe T, Kawamoto K, Yasuda T, et al. Eight days KAATSU-resistance training improved sprint but not jump performance in collegiate male track and field athletes. Int J KAATSU Training Res. 2005; 1(1):19-23.

27. Karabulut M, Abe T, Sato Y, et al. The effects of low-intensity resistance training with vascular restriction on leg muscle strength in older men. Eur J Appl Physiol. 2010; 108(1):147-155.

28. Yasuda T, Abe T, Sato Y, et al. Muscle fiber cross-sectional area is increased after two weeks of twice daily KAATSU-resistance training. Int J KAATSU Training Res. 2005; 1(2):65-70.

29. Takarada Y, Sato Y, Ishii N. Effects of resistance exercise combined with vascular occlusion on muscle function in athletes. Eur J Appl Physiol. 2002; 86(4):308-314.

30. Karabulut M, Bemben DA, Sherk VD, et al. Effects of high-intensity resistance training and low-intensity resistance training with vascular restriction on bone markers in older men. Eur J Appl Physiol. 2011; 111(8):1559-1567.

31. Fahs CA, Rossow LM, Loenneke JP, et al. Effect of different types of lower body resistance training on arterial compliance and calf blood flow. Clin Physiol Funct Imaging. 2011; 32(1):45-51.

32. Abe T, Beekley MD, Hinata S, et al. Day-to-day change in muscle strength and MRI-measured skeletal muscle size during 7 days KAATSU resistance training: A case study. Int J KAATSU Training Res. 2005; 1(2):71-76.

33. Abe T, Yasuda T, Midorikawa T, et al. Skeletal muscle size and circulating IGF-1 are increased after two weeks of twice daily "KAATSU" resistance training. Int J KAATSU Training Res. 2005; 1(6-12.

34. Clark BC, Manini TM, Hoffman RL, et al. Relative safety of 4 weeks of blood flow-restricted resistance exercise in young, healthy adults. Scand $J$ Med Sci Sports. 2011; 21(5):653-662.

35. Cook SB, Brown KA, Deruisseau K, et al. Skeletal muscle adaptations following blood flow-restricted training during 30 days of muscular unloading. J Appl Physiol. 2010; 109(2):341-349.

36. Loenneke JP, Fahs CA, Rossow LM, et al. Effects of cuff width on arterial occlusion: implications for blood flow restricted exercise. Eur J Appl Physiol. 2011;

37. Yasuda T, Brechue WF, Fujita T, et al. Muscle activation during lowintensity muscle contractions with varying levels of external limb compression. J Sports Sci Med. 2008; 7(467-474.

38. Takada S, Okita K, Suga T, et al. Blood Flow Restriction Exercise in Sprinters and Endurance Runners. Med Sci Sports Exerc. 2012;

39. Laurentino G, Ugrinowitsch C, Aihara AY, et al. Effects of strength training and vascular occlusion. Int J Sports Med. 2008; 29(8):664-667.

40. Laurentino GC, Ugrinowitsch C, Roschel H, et al. Strength Training with Blood Flow Restriction Diminishes Myostatin Gene Expression. Med Sci Sports Exerc. 2011;

41. Cook SB, Clark BC, Ploutz-Snyder LL. Effects of exercise load and bloodflow restriction on skeletal muscle function. Med Sci Sports Exerc. 2007; 39(10):1708-1713

42. Suga T, Okita K, Morita N, et al. Dose effect on intramuscular metabolic stress during low-intensity resistance exercise with blood flow restriction. J Appl Physiol. 2010; 108(6):1563-1567.

43. Sugaya M, Yasuda T, Suga T, et al. Change in intramuscular inorganic phosphate during multiple sets of blood flow-restricted low-intensity exercise. Clin Physiol Funct Imaging. 2011; 31(5):411-413.

44. Sumide T, Sakuraba K, Sawaki K, et al. Effect of resistance exercise training combined with relatively low vacular occlusion. J Sci Med Sport. 2009; 12(1):107-112.

45. Yasuda T, Abe T, Brechue WF, et al. Venous blood gas and metabolite 
response to low-intensity muscle contractions with external limb compression. Metabolism. 2010; 59(10):1510-1519.

46. Nakajima T, Kurano M, Sakagami F, et al. Effects of low-intensity KAATSU resistance training on skeletal muscle size/strength and endurance capacity in patients with ischemic heart disease. Int J KAATSU Training Res. 2010; 6(1):1-7.

47. Suga T, Okita K, Takada S, et al. Effect of multiple set on intramuscular metabolic stress during low-intensity resistance exercise with blood flow restriction. Eur J Appl Physiol. 2012;

48. Evans C, Vance S, Brown M. Short-term resistance training with blood flow restriction enhances microvascular filtration capacity of human calf muscles. J Sports Sci. 2010; 28(9):999-1007.

49. Kubo K, Komuro T, Ishiguro N, et al. Effects of low-load resistance training with vascular occlusion on the mechanical properties of muscle and tendon. J Appl Biomech. 2006; 22(2):112-119.

50. Sata S. Kaatsu training for patella tendinitis patient. Int J KAATSU Training Res. 2005; 1(1):29-32.

51. Patterson SD, Ferguson RA. Increase in calf post-occlusive blood flow and strength following short-term resistance exercise training with blood flow restriction in young women. Eur J Appl Physiol. 2010; 108(5):1025-1033.

52. Patterson SD, Ferguson RA. Enhancing strength and postocclusive calf blood flow in older people with training with blood-flow restriction. $J$ Aging Phys Act. 2011; 19(3):201-213.

53. Gualano B, Neves M, Jr., Lima FR, et al. Resistance training with vascular occlusion in inclusion body myositis: a case study. Med Sci Sports Exerc. 2010; 42(2):250-254
54. Sakuraba K, Ishikawa T. Effect of isokinetic resistance training under a condition of restricted blood flow with pressure. J Orthop Sci. 2009; 14(5):631-639.

55. Abe T, Kearns CF, Fujita $\mathrm{S}$, et al. Skeletal muscle size and strength are increased following walk training with restricted leg muscle blood flow: implications for training duration and frequency. Int $J$ KAATSU Training Res. 2009; 5(1):9-15.

56. Umbel JD, Hoffman RL, Dearth DJ, et al. Delayed-onset muscle soreness induced by low-load blood flow-restricted exercise. Eur J Appl Physiol. 2009; 107(6):687-695.

57. Wernbom M, Paulsen G, Nilsen TS, et al. Contractile function and sarcolemmal permeability after acute low-load resistance exercise with blood flow restriction. Eur J Appl Physiol. 2011;

58. Ohta $\mathrm{H}$, Kurosawa $\mathrm{H}$, Ikeda $\mathrm{H}$, et al. Low-load resistance muscular training with moderate restriction of blood flow after anterior cruciate ligament reconstruction. Acta Orthop Scand. 2003; 74(1):62-68.

59. Yokokawa Y, Hongo M, Urayama H, et al. Effects of low-intensity resistance exercise with vascular occlusion on physical function in healthy elderly people. Biosci Trends. 2008; 2(3):117-123.

60. Credeur DP, Hollis BC, Welsch MA. Effects of Handgrip Training With Venous Restriction on Brachial Artery Vasodilation. Med Sci Sports Exerc. 2009; 42(7):1296-1302.

61. Shinohara M, Kouzaki M, Yoshihisa T, et al. Efficacy of tourniquet ischemia for strength training with low resistance. Eur J Appl Physiol Occup Physiol. 1998; 77(1-2):189-191.

Table 1. Summary of BFR resistance exercise training studies.

\begin{tabular}{|c|c|c|c|c|c|c|c|c|c|c|}
\hline $\begin{array}{l}\text { Citation } \\
\text { Number }\end{array}$ & $\begin{array}{l}\text { Limbs } \\
\text { (arms/legs) }\end{array}$ & Exercises & $\begin{array}{l}\text { Cuff } \\
\text { Pressure }\end{array}$ & $\begin{array}{l}\text { Cuff } \\
\text { Width }\end{array}$ & $\begin{array}{l}\text { Continuous/ } \\
\text { intermittent } \\
\text { BFR }\end{array}$ & $\begin{array}{l}\text { Exercise } \\
\text { Load }\end{array}$ & $\begin{array}{l}\text { Frequency } \\
\text { of Training }\end{array}$ & $\begin{array}{l}\text { Length of } \\
\text { Training }\end{array}$ & $\begin{array}{l}\text { Protocol (sets, } \\
\text { reps, and rest } \\
\text { interval) }\end{array}$ & Comments \\
\hline 33 & Legs & $\begin{array}{l}\text { Squat and knee } \\
\text { flexion }\end{array}$ & $\begin{array}{l}160-240 \\
\mathrm{mmHg} *\end{array}$ & $5 \mathrm{~cm}^{\S}$ & $\begin{array}{l}\text { Continuous } \\
(10 \mathrm{~min})\end{array}$ & $20 \% 1-\mathrm{RM}$ & $12 \mathrm{x}$ week & 2 weeks & $\begin{array}{l}3 \text { sets of } 15 \\
\text { repetitions; } \\
30 \text { sec rest }\end{array}$ & \\
\hline 26 & Legs & $\begin{array}{l}\text { Squat and knee } \\
\text { flexion }\end{array}$ & $\begin{array}{l}160-240 \\
\mathrm{mmHg} *\end{array}$ & $5 \mathrm{~cm}^{\S}$ & Continuous & $20 \% 1-\mathrm{RM}$ & $14 \mathrm{x}$ week & 8 days & $\begin{array}{l}3 \text { sets of } 15 \\
\text { repetitions; } \\
30 \text { sec rest }\end{array}$ & $\begin{array}{l}\text { Population of } \\
\text { athletes }\end{array}$ \\
\hline 32 & Legs & Knee extension & $\begin{array}{l}160-220 \\
\mathrm{mmHg} *\end{array}$ & $5 \mathrm{~cm}^{\S}$ & Continuous & $20 \% 1-\mathrm{RM}$ & $14 \mathrm{x}$ week & 1 week & $\begin{array}{l}3 \text { sets of } 15 \\
\text { repetitions; } \\
30 \text { sec rest }\end{array}$ & Case study \\
\hline 16 & Arms & $\begin{array}{l}\text { Unilateral elbow } \\
\text { flexion }\end{array}$ & $100 \mathrm{mmHg}$ & $12 \mathrm{~cm}$ & $\begin{array}{l}\text { Intermittent } \\
\text { ( } 2 \text { separate } \\
\text { training blocks) }\end{array}$ & $50 \% 1-\mathrm{RM}$ & $2 \mathrm{x}$ week & 8 weeks & $\begin{array}{l}3-6 \text { sets (final } \\
\text { set to failure); } \\
60 \mathrm{sec} \text { rest }\end{array}$ & $\begin{array}{l}\text { Progressive } \\
\text { increases in } \\
\text { training volume }\end{array}$ \\
\hline 34 & Legs & Knee extension & $1.3^{*} \mathrm{SBP}$ & $6 \mathrm{~cm}$ & Continuous & $30 \% 1-\mathrm{RM}$ & $3 \mathrm{x}$ week & 4 weeks & $\begin{array}{l}3 \text { sets to fatigue; } \\
90 \text { sec rest }\end{array}$ & \\
\hline 35 & Legs & Knee extension & $1.3^{*} \mathrm{SBP}$ & $6 \mathrm{~cm}$ & $\begin{array}{l}\text { Continuous } \\
(8.5 \mathrm{~min})\end{array}$ & $20 \% \mathrm{MVC}$ & $3 \mathrm{x}$ week & $\begin{array}{l}4 \text { weeks } \\
\text { (30 days) }\end{array}$ & $\begin{array}{l}3 \text { sets to fatigue; } \\
90 \mathrm{sec} \text { rest }\end{array}$ & \\
\hline 60 & Arms & Handgrip training & $80 \mathrm{mmHg}$ & $\begin{array}{l}\text { Not } \\
\text { Reported }\end{array}$ & $\begin{array}{l}\text { Continuous } \\
(20 \mathrm{~min})\end{array}$ & $60 \% \mathrm{MVC}$ & $3 \mathrm{x}$ week & 4 weeks & $\begin{array}{l}15 \text { contractions/ } \\
\text { min for } 20 \mathrm{~min}\end{array}$ & $\begin{array}{l}\text { Reported } 100 \\
\text { mmHg pressure } \\
\text { caused discomfort }\end{array}$ \\
\hline 48 & Legs & Heel raises & $150 \mathrm{mmHg}$ & $15 \mathrm{~cm}$ & $\begin{array}{l}\text { Intermittent } \\
\text { (deflated } \\
\text { between sets) }\end{array}$ & Body mass & $3 \mathrm{x}$ week & 4 weeks & $\begin{array}{l}4 \text { sets of } 50 \\
\text { repetitions; } \\
60 \text { sec rest }\end{array}$ & $\begin{array}{l}\text { Progressive added } \\
\text { external load } \\
\text { during training }\end{array}$ \\
\hline 31 & Leg & $\begin{array}{l}\text { Knee extension } \\
\text { and flexion }\end{array}$ & $\begin{array}{l}160-200 \\
\mathrm{mmHg} *\end{array}$ & $5 \mathrm{~cm}$ & Continuous & $20 \% 1-\mathrm{RM}$ & $3 \mathrm{x}$ week & 6 weeks & $\begin{array}{l}30-15-15-15 \\
\text { repetitions; } \\
60 \text { sec rest }\end{array}$ & \\
\hline 9 & Legs & Knee extension & $\begin{array}{l}160-220 \\
\mathrm{mmHg} *\end{array}$ & $5 \mathrm{~cm}^{\S}$ & Continuous & $20 \% 1-\mathrm{RM}$ & $12 \mathrm{x}$ week & 6 days & $\begin{array}{l}30-15-15-15 \\
\text { repetitions; } \\
30 \text { sec rest }\end{array}$ & \\
\hline
\end{tabular}


Table 1. continued

\begin{tabular}{|c|c|c|c|c|c|c|c|c|c|c|}
\hline $\begin{array}{l}\text { Citation } \\
\text { Number }\end{array}$ & $\begin{array}{l}\text { Limbs } \\
\text { (arms/legs) }\end{array}$ & Exercises & $\begin{array}{l}\text { Cuff } \\
\text { Pressure }\end{array}$ & $\begin{array}{l}\text { Cuff } \\
\text { Width }\end{array}$ & $\begin{array}{l}\text { Continuous/ } \\
\text { intermittent } \\
\text { BFR }\end{array}$ & $\begin{array}{l}\text { Exercise } \\
\text { Load }\end{array}$ & $\begin{array}{l}\text { Frequency } \\
\text { of Training }\end{array}$ & $\begin{array}{l}\text { Length of } \\
\text { Training }\end{array}$ & $\begin{array}{l}\text { Protocol (sets, } \\
\text { reps, and rest } \\
\text { interval) }\end{array}$ & Comments \\
\hline 53 & Legs & $\begin{array}{l}\text { Leg press, knee } \\
\text { extension, squat }\end{array}$ & $\begin{array}{l}50 \% \text { total } \\
\text { occlusion } \\
\text { pressure }\end{array}$ & $\begin{array}{l}\text { Not } \\
\text { Reported }\end{array}$ & Continuous & $15-\mathrm{RM}$ & $2 \mathrm{x}$ week & 12 weeks & $\begin{array}{l}3 \text { sets of } \\
15 \text { repetitions; } \\
30 \text { sec rest }\end{array}$ & $\begin{array}{l}\text { Effective in } \\
\text { combating muscle } \\
\text { atrophy in an } \\
\text { individual with } \\
\text { inclusion body } \\
\text { myositis }\end{array}$ \\
\hline 4 & $\begin{array}{l}\text { Legs and } \\
\text { Arms }\end{array}$ & $\begin{array}{l}\text { Knee up, bent-knee } \\
\text { push up, leg raise, } \\
\text { knee flexion, squat, } \\
\text { lunge }\end{array}$ & $\begin{array}{l}50-80 \\
\mathrm{mmHg} \\
\text { (upper limbs) } \\
80-120 \\
\mathrm{mmHg} \\
\text { (lower limbs) }\end{array}$ & N/a & Continuous & Body mass & $3 \mathrm{x}$ week & 8 weeks & $\begin{array}{l}1-2 \text { sets, } 10-50 \\
\text { reps per set; } \\
\sim 10 \text { sec rest }\end{array}$ & $\begin{array}{l}\text { Progressive } \\
\text { increases in } \\
\text { training volume }\end{array}$ \\
\hline 11 & Leg & $\begin{array}{l}\text { Unilateral knee } \\
\text { extension }\end{array}$ & $230 \mathrm{mmHg}$ & $13 \mathrm{~cm}$ & Intermittent & $15 \% \mathrm{MVC}$ & $4 \mathrm{x}$ week & 4 weeks & $\begin{array}{l}4 \text { sets to } \\
\text { volitional } \\
\text { fatigue }\end{array}$ & $\begin{array}{l}\text { Observed less } \\
\text { hypertrophy at site } \\
\text { of cuff application }\end{array}$ \\
\hline 27 & Legs & $\begin{array}{l}\text { Leg press, knee } \\
\text { extension }\end{array}$ & $\begin{array}{l}160-240 \\
\mathrm{mmHg} *\end{array}$ & $5 \mathrm{~cm}$ & $\begin{array}{l}\text { Intermittent } \\
\text { (deflated } \\
\text { between } \\
\text { exercises 5-10 } \\
\text { min) }\end{array}$ & $20 \% 1-R M$ & $3 \mathrm{x}$ week & 6 weeks & $\begin{array}{l}30,15,15 \\
\text { repetitions; } \\
60 \text { sec rest }\end{array}$ & $\begin{array}{l}\text { Increased } \\
\text { restrictive cuff } \\
\text { pressure based on } \\
\text { RPE }\end{array}$ \\
\hline 30 & Legs & $\begin{array}{l}\text { Leg press, knee } \\
\text { extension }\end{array}$ & $\begin{array}{l}160-240 \\
\mathrm{mmHg} *\end{array}$ & $5 \mathrm{~cm}$ & $\begin{array}{l}\text { Intermittent } \\
\text { (deflated } \\
\text { between } \\
\text { exercises 5-10 } \\
\text { min) }\end{array}$ & $20 \% 1-R M$ & $3 \mathrm{x}$ week & 6 weeks & $\begin{array}{l}30,15,15 \\
\text { repetitions; } \\
30 \text { sec rest }\end{array}$ & $\begin{array}{l}\text { Increased } \\
\text { restrictive cuff } \\
\text { pressure based on } \\
\text { RPE }\end{array}$ \\
\hline 49 & Leg & $\begin{array}{l}\text { Unilateral knee } \\
\text { extension }\end{array}$ & $\begin{array}{l}\text { Not } \\
\text { reported* }\end{array}$ & $\begin{array}{l}\text { Not } \\
\text { Reported }\end{array}$ & Continuous & $20 \% 1-R M$ & $3 \mathrm{x}$ week & 12 weeks & $\begin{array}{l}25,18,15,12 \\
\text { repetitions; } \\
30 \text { sec rest }\end{array}$ & $\begin{array}{l}\text { Increase in } \\
\text { strength but not } \\
\text { specific tension }\end{array}$ \\
\hline 39 & Leg & $\begin{array}{l}\text { Unilateral knee } \\
\text { extension }\end{array}$ & $\begin{array}{l}\sim 126-131 \\
\mathrm{mmHg}\end{array}$ & $14 \mathrm{~cm}$ & Intermittent & $\begin{array}{l}\text { Moderate } \\
\text { intensity: } \\
\text { 12RM }(60 \% \\
\text { 1-RM) } \\
\text { High intensity } \\
6 \text { RM ( } 80 \% \\
\text { 1-RM) }\end{array}$ & $2 \mathrm{x}$ week & 8 weeks & $\begin{array}{l}12 \text { or } 6 \text { reps } \\
\text { per set; } 120 \\
\text { sec rest }\end{array}$ & $\begin{array}{l}\text { Progressive } \\
\text { increase in exercise } \\
\text { volume (\# sets) }\end{array}$ \\
\hline 40 & Legs & Knee extension & $\begin{array}{l}\sim 95 \mathrm{mmHg} \\
\text { (80\% of } \\
\text { pressure for } \\
\text { complete } \\
\text { arterial } \\
\text { occlusion) }\end{array}$ & $17.5 \mathrm{~cm}$ & Continuous & $20 \% 1-R M$ & $2 \mathrm{x}$ week & 8 weeks & $\begin{array}{l}3 \text { sets of } 15 \\
\text { repetitions }\end{array}$ & \\
\hline 8 & Legs & $\begin{array}{l}\text { Knee extension } \\
\text { and knee flexion }\end{array}$ & $\begin{array}{l}160-240 \\
\mathrm{mmHg} *\end{array}$ & $4 \mathrm{~cm}$ & Continuous & $30 \%$ 1-RM & $2 \mathrm{x}$ week & 10 weeks & $\begin{array}{l}30,15,15 \\
\text { repetitions; } \\
30 \text { sec rest }\end{array}$ & \\
\hline 15 & Arms & $\begin{array}{l}\text { Unilateral elbow } \\
\text { flexion }\end{array}$ & $100 \mathrm{mmHg}$ & $7 \mathrm{~cm}$ & $\begin{array}{l}\text { Intermittent } \\
\text { (2 separate } \\
\text { training blocks) }\end{array}$ & $50 \% 1-\mathrm{RM}$ & $2 \mathrm{x}$ week & 8 weeks & $\begin{array}{l}3-6 \text { sets (final } \\
\text { set to fatigue); } \\
60 \mathrm{sec} \text { rest }\end{array}$ & $\begin{array}{l}\text { Progressive } \\
\text { increases in } \\
\text { training volume }\end{array}$ \\
\hline 46 & Legs & $\begin{array}{l}\text { Leg press, knee } \\
\text { flexion and } \\
\text { extension }\end{array}$ & $\begin{array}{l}100-250 \\
\mathrm{mmHg} *\end{array}$ & $\begin{array}{l}\text { Not } \\
\text { reported }\end{array}$ & Continuous & $20 \% 1-\mathrm{RM}$ & $2 \mathrm{x}$ week & 12 weeks & $\begin{array}{l}30,15,15,15, \\
15 ; 1 \text { min rest }\end{array}$ & $\begin{array}{l}\text { Population of } \\
\text { patients with } \\
\text { ischemic heart } \\
\text { disease }\end{array}$ \\
\hline 58 & $\begin{array}{l}\text { Leg } \\
\text { (unilateral) }\end{array}$ & $\begin{array}{l}\text { Rehabilitation } \\
\text { exercises }\end{array}$ & $180 \mathrm{mmHg}$ & $\begin{array}{l}\text { Not } \\
\text { Reported }\end{array}$ & $\begin{array}{l}\text { Not } \\
\text { Reported }\end{array}$ & Variable & $6 \mathrm{x}$ week & 16 weeks & Variable & $\begin{array}{l}\text { Progressive } \\
\text { increases in } \\
\text { training load and } \\
\text { volume }\end{array}$ \\
\hline 51 & Leg & $\begin{array}{l}\text { Unilateral } \\
\text { plantar flexion }\end{array}$ & $110 \mathrm{mmHg}$ & $18.5 \mathrm{~cm}^{\S}$ & $\begin{array}{l}\text { Continuous } \\
\text { (5-8 min) }\end{array}$ & $\begin{array}{l}25 \% \text { or } 50 \% \\
1-\mathrm{RM}\end{array}$ & $3 \mathrm{x}$ week & 4 weeks & $\begin{array}{l}3 \text { sets to fatigue; } \\
60 \mathrm{sec} \text { rest }\end{array}$ & $\begin{array}{l}\text { Greater increases } \\
\text { in strength with } \\
50 \% 1-\mathrm{RM}\end{array}$ \\
\hline 52 & Leg & $\begin{array}{l}\text { Unilateral } \\
\text { plantar flexion }\end{array}$ & $110 \mathrm{mmHg}$ & $\begin{array}{l}\text { Not } \\
\text { Reported }\end{array}$ & $\begin{array}{l}\text { Continuous } \\
\text { (5-8 min) }\end{array}$ & $25 \% 1-\mathrm{RM}$ & $3 \mathrm{x}$ week & 4 weeks & $\begin{array}{l}3 \text { sets to fatigue; } \\
60 \text { sec rest }\end{array}$ & $\begin{array}{l}\text { Enhanced post- } \\
\text { occlusive blood } \\
\text { flow in older } \\
\text { participants with } \\
\text { BFR exercise }\end{array}$ \\
\hline
\end{tabular}


Table 1. continued

\begin{tabular}{|c|c|c|c|c|c|c|c|c|c|c|}
\hline $\begin{array}{l}\text { Citation } \\
\text { Number }\end{array}$ & $\begin{array}{l}\text { Limbs } \\
\text { (arms/legs) }\end{array}$ & Exercises & $\begin{array}{l}\text { Cuff } \\
\text { Pressure }\end{array}$ & $\begin{array}{l}\text { Cuff } \\
\text { Width }\end{array}$ & $\begin{array}{l}\text { Continuous/ } \\
\text { intermittent } \\
\text { BFR }\end{array}$ & $\begin{array}{l}\text { Exercise } \\
\text { Load }\end{array}$ & $\begin{array}{l}\text { Frequency } \\
\text { of Training }\end{array}$ & $\begin{array}{l}\text { Length of } \\
\text { Training }\end{array}$ & $\begin{array}{l}\text { Protocol (sets, } \\
\text { reps, and rest } \\
\text { interval) }\end{array}$ & Comments \\
\hline 54 & Legs & $\begin{array}{l}\text { Isokinetic knee } \\
\text { extension/flexion }\end{array}$ & $200 \mathrm{mmHg}$ & $7.7 \mathrm{~cm}^{\S}$ & Not Reported & $\begin{array}{l}300^{\circ} / \mathrm{sec} \text { and } \\
90^{\circ} / \mathrm{sec}\end{array}$ & $2 \mathrm{x}$ week & 4 weeks & $\begin{array}{l}3 \text { sets of } 10 \text { reps; } \\
60 \text { sec rest }\end{array}$ & $\begin{array}{l}\text { Participants } \\
\text { complained of pain } \\
\text { during training } \\
\text { with } 250 \mathrm{mmHg} \\
\text { pressure }\end{array}$ \\
\hline 61 & $\begin{array}{l}\text { Leg } \\
\text { (unilateral) }\end{array}$ & $\begin{array}{l}\text { Isometric } \\
\text { contractions }\end{array}$ & $>250 \mathrm{mmHg}$ & $8 \mathrm{~cm}$ & $\begin{array}{l}\text { Continuous } \\
(3 \mathrm{~min})\end{array}$ & $40 \%$ MVC & $3 \mathrm{x}$ week & 4 weeks & $\begin{array}{l}362 \text {-second } \\
\text { contractions; } \\
3 \text { sec rest }\end{array}$ & \\
\hline 12 & $\begin{array}{l}\text { Arm } \\
\text { (unilateral) }\end{array}$ & Elbow flexion & $\sim 110 \mathrm{mmHg}$ & $3.3 \mathrm{~cm}$ & $\begin{array}{l}\text { Continuous } \\
(5 \mathrm{~min})\end{array}$ & $50 \% 1-\mathrm{RM}$ & $2 \mathrm{x}$ week & 16 weeks & $\begin{array}{l}3 \text { sets to failure; } \\
60 \mathrm{sec} \text { rest }\end{array}$ & $\begin{array}{l}\text { Population of } \\
\text { post-menopausal } \\
\text { women }\end{array}$ \\
\hline 29 & Legs & Knee extension & $\sim 196 \mathrm{mmHg}$ & $3.3 \mathrm{~cm}$ & $\begin{array}{l}\text { Continuous } \\
(10 \mathrm{~min})\end{array}$ & $50 \% 1-\mathrm{RM}$ & $2 \mathrm{x}$ week & 8 weeks & $\begin{array}{l}4 \text { sets of } \sim 16 \\
\text { repetitions; } \\
30 \text { sec rest }\end{array}$ & $\begin{array}{l}\text { Effective for } \\
\text { increasing muscle } \\
\text { hypertrophy, } \\
\text { strength and } \\
\text { endurance in elite } \\
\text { rugby players }\end{array}$ \\
\hline 18 & $\begin{array}{l}\text { Arms and } \\
\text { legs }\end{array}$ & $\begin{array}{l}\text { Squat and } \\
\text { bench press }\end{array}$ & $\begin{array}{l}\text { N/a (elastic } \\
\text { bands) }\end{array}$ & $5 \mathrm{~cm}$ & Continuous & $20 \% 1-\mathrm{RM}$ & $3 \mathrm{x}$ week & 4 weeks & $\begin{array}{l}30-20-20-20 \\
\text { repetitions; } \\
45 \text { sec rest }\end{array}$ & $\begin{array}{l}\text { Training was } \\
\text { effective for } \\
\text { increasing strength } \\
\text { and limb size when } \\
\text { added to off-season } \\
\text { conditioning } \\
\text { program in Division } \\
\text { I football players }\end{array}$ \\
\hline 28 & Legs & $\begin{array}{l}\text { Squat and knee } \\
\text { flexion }\end{array}$ & $\begin{array}{l}160-240 \\
\mathrm{mmHg} *\end{array}$ & $5 \mathrm{~cm}^{\S}$ & Continuous & $20 \% 1-\mathrm{RM}$ & $12 \mathrm{x}$ week & 2 weeks & $\begin{array}{l}3 \text { sets of } 15 \\
\text { repetitions; } \\
30 \text { sec rest }\end{array}$ & \\
\hline 13 & Arms & Bench press & $\begin{array}{l}100-160 \\
\text { mmHg* }\end{array}$ & $3 \mathrm{~cm}^{\S}$ & Continuous & $30 \% 1-\mathrm{RM}$ & $12 \mathrm{x}$ week & 2 weeks & $\begin{array}{l}30-15-15-15 \\
\text { repetitions; } \\
30 \text { sec rest }\end{array}$ & \\
\hline 6 & Arms & Bench press & $\begin{array}{l}100-160 \\
\mathrm{mmHg}\end{array}$ & $3 \mathrm{~cm}^{\S}$ & Continuous & $30 \% 1-R M$ & $3 \mathrm{x}$ week & 6 weeks & $\begin{array}{l}30-15-15-15 \\
\text { repetitions; } \\
30 \text { sec rest }\end{array}$ & \\
\hline 14 & Arms & Bench press & $\begin{array}{l}100-160 \\
\mathrm{mmHg} *\end{array}$ & $3 \mathrm{~cm}^{\S}$ & Continuous & $30 \% 1-\mathrm{RM}$ & $3 \mathrm{x}$ week & 6 weeks & $\begin{array}{l}30-15-15-15 \\
\text { repetitions; } \\
30 \text { sec rest }\end{array}$ & \\
\hline 59 & Legs & $\begin{array}{l}\text { Physical } \\
\text { therapy program }\end{array}$ & $\begin{array}{l}1.2 * \mathrm{SBP} \\
(70-150 \\
\mathrm{mmHg})^{*}\end{array}$ & $4.5 \mathrm{~cm}$ & Continuous & Bodyweight & $2 \mathrm{x}$ week & 8 weeks & Not reported & $\begin{array}{l}\text { Improved strength } \\
\text { and functional } \\
\text { ability in older } \\
\text { adults }\end{array}$ \\
\hline
\end{tabular}

* Denotes progressive increase in restrictive cuff pressure during training; ${ }^{\S}$ not reported in manuscript, information received via personal communication 